\title{
AGAMA, KEKERASAN DAN PERLAWANAN IDEOLOGIS
}

\author{
Umi Sumbulah*
}

\begin{abstract}
A bstract: Violence in the name of religion often occurs because of the ideological interpretation of religion. Well-formulated ideology is obeyed by its followers to achieve certain goals. Ideology may also be appropriated by its proponents to rebel against the status quo that they think is not in line with their belief system. A closed-ideology that perpetuates intolerance is a latent source of conflict and violence. In addition, many religion-oriented violence is associated not only with religion per se as a source of inspiration and legitimacy, but also with such factors as social, economic, political as well as psychological conditions of human being. One-sided explanation of violence in the name of religion is therefore insufficient as religion is not monolithic phenomenon.
\end{abstract}

Keywords: religious violence, ideology

\section{Pendahuluan}

Secara normatif, teks-teks agama bersifat ambivalen. la bisa menebar kedamaian karena pesan-pesan suci perdamaiannya. Namun ia juga bisa rentan memicu konflik dan kekerasan karena pesan-pesan tekstualitasnya mengandung kekerasan. Dalam konteks Islam, beberapa teks yang memicu dan melahirkan perilaku kekerasan pada kelompok gerakan radikal antara lain dapat dilihat misalnya pada teks tentang jihad, yang kemudian disistematisir sebagai ideologi perang sehingga sarat kekerasan. Namun bagi gerakan radikal, jihad dilakukan atas dasar keyakinan yang dapat dipertanggung jawabkan kebenarannya dan dapat diuji otentisitas sumber hukumnya.

\section{Agama dan Perlawanan Ideologis}

Ideologi merupakan argumen yang muncul dari pandangan dunia atau paradigma sosial yang digunakan oleh sekelompok orang untuk menjustifikasi tindakan mereka. ${ }^{1}$ Pandangan dunia maupun paradigma sosial sesungguhnya tidak sekedar keyakinan tentang kata-kata yang diinginkan atau dimaksudkan menuntun tindakan, namun juga memiliki legitimasi atau justifikasi terhadap sebab-sebab tindakan kekerasan tersebut dilakukan. Dengan demikian, ketika kelompok gerakan kekerasan ini menghubungkan perilakunya dengan pandangan hidup, pandangan agama atau paradigma sosial yang ditegakkan sebagai sebuah ideologi, maka ekspresi tindakan kekerasan yang dilakukannya lebih memungkinkan untuk bisa dipahami pihak lain.

Ketika sebuah paradigma sosial atau pandangan agama difungsikan sebagai ideologi, maka ia akan memiliki dua karakteristik, yakni: pertama, ideologi diformulasi dan ditaati oleh penganutnya untuk mencapai tujuan tertentu; kedua, ideologi digunakan oleh proponennya untuk mencapai tujuan politik mereka. Dalam konteks ini, penggunaan ideologi dilakukan sebagai pendorong dan penguat kekerasan, privelege dan tindakan mereka, atau dengan kata

\footnotetext{
*UIN Malang, JI. Gajayana 50 Malang, e-mail: umi_sumbullah@yahoo.com, telepon: 08123399922.

${ }^{1}$ Graham C. Kinloch, Ideology and the Social Science (t.tp.: Greenwoon Press, 1981), 78.
} 
lain ideologi merupakan simbol senjata politik.

Sebuah ideologi bekerja mengikuti alur rasionalitas, di mana makna atau ide akan mempengaruhi konsepsi dan aktivitas individu maupun kelompok yang membentuk dunia sosial. Oleh karena itu, studi bahasa yang memiliki kekuatan memobilisir individu atau sebuah kelompok dalam dunia sosial, mendapatkan posisi istimewa. Ideologi, sebagai sebuah sistem simbol, memiliki korelasi yang kuat dengan tindakan sosial. Wacana permusuhan dan konfrontatif yang diusung oleh gerakan Islam "radikal" terhadap agama Kristen dan Yahudi menjadi sebuah kekuatan tidak saja bagaimana kelompok ini memandang kedua agama tersebut, namun juga bisa menjadi potensi laten yang sewaktu-waktu dapat memunculkan konflik dan kekerasan. ${ }^{2}$

Karakteristik ideologi mengandaikan kecenderungan intoleran terhadap cara-cara berpikir atau epistemologi berpikir yang lain. Oleh karena itu, ketika mengekspresikan idenya pada obyek yang mereka sebut sebagai musuh, hal itu karena mereka memiliki parameter tersendiri ketika mendefinisikan seseorang atau pihak lain sebagai musuh. Bagi mereka, musuh adalah semua orang yang tidak memiliki kesamaan visi dan ideologi. Dengan demikian, definisi tentang sesuatu tidak didasarkan kepada pandangan umum, tetapi didasarkan pada kepentingan ideologi mereka sendiri. Kebaikan, kebenaran, dan moralitas yang berhak menafsirkan Tuhan adalah "aku" ${ }^{3}$. Oleh karena itu, dapat dipahami mengapa misalnya para pelaku kekerasan mengebom Sari Club dan Pady's Café Legian Bali yang ditengarai banyak dikunjungi orang Barat, terutama Australia dan Amerika. Bagi kelompok ini, Barat adalah the great satan. Amerika dan sekutunya dinilai telah memecah belah dunia Muslim, pendukung kebijakan zionisme Israel yang meluluh lantakkan kemanusiaan di bumi Palestina yang telah dihuni oleh etnis Arab-Muslim Palestina. Karena itu, perilaku kekerasan yang dilakukan kelompok ini diyakini sebagai jihad fi sabiłAllah melawan teroris, yakni Amerika. ${ }^{4}$

Ideologi jihad yang dipahami sebagai legitimasi kekerasan, karena jihad diyakini sebagai berperang melawan kaum kafir yang memerangi Islam dan membunuh kaum Muslimin. Dalam konteks ini, kendati sesungguhnya sebutan kafir dan munafiq bagi Zionis (Yahudi) dan Salibis (Kristen) kurang pada tempatnya, namun ideologi tersebut telah mengkristal sebagai ideologi jihad bagi pelaku kekerasan.

Dalam konteks ini pula, dapat disimak interpretasi yang dilakukan oleh para ideolog agama, seperti al-Mawdudi>yang menyerukan angkat senjata. Bagi al-Mawdudi>jihad adalah perjuangan revolusioner untuk merebut kekuasaan demi kebaikan seluruh umat manusia. Hal serupa bisa dilihat dalam ideologi perjuangan Islam Iran melawan rezim Shah yang dipimpin oleh Imam Khomeini, yang terilhami oleh ajaran Mulla Sadra. ${ }^{5}$ Bagi Sadra, mistisisme dan politik tidak dapat dipisahkan, dan karenanya reformasi sosial tidak mungkin tercapai tanpa dibarengi reformasi spiritual, yang hal ini dilakukan dengan jihad.

J ihad adalah kewajiban paling penting yang diabaikan dari semua kewajiban agama. Untuk mengamalkan kekerasan suci ini, pedang adalah satu-satunya cara menegakkan masyarakat

\footnotetext{
${ }^{2} \mathrm{~J}$ ohn B. Tompson, Analisis Id eo logi: Kritik Wacana Ideologi-ideologi Dunia (Yogyakarta: IRCiSoD, 2003), 127-128.

${ }^{3}$ Armada Riyanto, "Genesis Terorisme", dalam Harian U mum Kompas, 22 O ktober 2002.

${ }^{4}$ Imam Samudera, Aku Melawan Teroris (Solo: Al-J azera, 2004), 87.

${ }^{5} \mathrm{~J}$ ohnson, Perang Suci atas Nama Tuhan, 196.
} 
yang adil, demikian Faraj, seorang aktivis dan pemikir yang literalis, yang banyak mengilhami gerakan kekerasan di berbagai wilayah bumi Muslim. ${ }^{6}$

J ihad bagi kelompok ini lebih dipahami sebagai perang fisik untuk mempertahankan dan memberlakukan hukum Tuhan. Kelompok ini, dengan mengatasnamakan Tuhan melakukan teror dan bahkan pengeboman, yang bagi mereka merupakan keyakinan inhern yang harus dilaksanakan dalam rangka amr ma'rufnahy munkar. Hal ini karena Islam telah dirusak oleh modernitas Barat yang telah menyebarkan sentimen keagamaan terhadap umat Islam di belahan bumi Muslim. Untuk kepentingan melawan Barat itulah, peran ideologi menjadi penting adanya.

Ideologi, merupakan daya penuntun bagi sebuah gerakan untuk mewujudkan tujuan akhirnya. Salah satu karakteristik ideologi adalah tidak akan pernah "mati". Ketika sebuah gerakan diberangus misalnya, maka ideologi yang telah dibangun oleh gerakan tersebut akan selalu muncul, baik dengan wujud yang sama maupun performa yang berbeda. $\mathrm{Hal}$ ini misalnya dapat dilihat pada ideologi Negara Islam Indonesia (NII). Meskipun organisasi ini telah menjadi bagian dari sejarah masa lalu Indonesia, namun ideologi yang diperjuangkan NII tampaknya menjadi inspirator tersendiri bagi gerakan Islam politik yang ada sekarang. Demikian juga fenomena gerakan usrah yang ditangkapi pada tahun 1984-an oleh rezim Orde Baru, namun ideologi usrah terus-menerus berkembang. H anya saja, tampilan ideologi usrah diterjemahkan dengan cara yang berbeda-beda oleh para aktivis gerakan Islam politik.

Perlawanan berbasis ideologi akan menjadi berbeda dengan gerakan perlawanan berbasis kelas, yang mendasarkan perlawanannya pada superstruktur ala Weber berupa tatanan ekonomipolitik, maupun substruktur ala Marx. Perlawanan kelas akan berhenti ketika sebuah capaian ekonomi-politik telah didapatkan. Tidak demikian dengan gerakan berbasis ideologi. Mereka terus akan mengelaborasi sisi-sisi ideologis dari apa yang mereka yakini sebagai sebuah kebenaran, yang harus secara terus-menerus diperjuangkan.

Ideologi merupakan sebuah sistem simbol atau kepercayaan yang berhubungan dengan tindakan sosial atau praktik politik. ${ }^{7}$ Karena itu, sebagaimana digagas Marx, sesungguhnya konsep ideologi tidak pernah dipisahkan dari kritik dominasi. Bahkan dengan ideologi yang dibangun, suatu kelompok masyarakat atau kelompok sosial-keagamaan tertentu bisa melakukan kritik dan memberikan reaksi terhadap fenomena ketidakadilan berbasis kelas. Ketidak adilan tersebut bisa pada tataran ekonomi maupun politik. Karena itu, ideologi dapat dinyatakan sebagai "wajah" kesadaran kelas yang diorientasikan pada tindakan politik.

Berdasarkan konsepsi ideologis yang tidak bisa dilepaskan dari kritik politik, Seliger sebagaimana dikutip Thompson - memberikan kesimpulan bahwa sebagai sebuah sistem yang membimbing dan mempertahankan tindakan politik, ideologi harus dikembalikan kepada sistem kepercayaan politiknya, baik bersifat revolusioner, reformis atau konservatif tradisional. Karena itu, ideologi didefinisikan Seliger sebagai orientasi tindakan (action-oriented) yang berisi kepercayaan yang diorganisir dalam sebuah sistem secara koheren. ${ }^{8}$

\footnotetext{
${ }^{6}$ Karen Armstrong, the Battle for God, Fundamentalism in J udaism, Cristianity and islam, (London: Harper Collins Publisher, 2003), 335.

7 J ohn B. Thompson, Analisis Ideologi, 129.

${ }^{8}$ Ibid., 131.
} 
Ideologi mesianik, yang dalam bahasa Derrida disebut sebagai mesianisme determinate, juga menjadi inspirasi tersendiri bagi perjuangan kelompok ini untuk mendapatkan kemenangan di masa mendatang. Harapan dan cita yang determinate tersebut menjadi kekuatan bagi spirit gerakan, untuk mendapatkan keadilan mesianik. Dalam kerangka struktur Marxisme, semangat ini dinilai sebagai sebuah keyakinan akan adanya suatu pembebasan dan penegasan mesianik tertentu. Produk dari ideologi ini adalah terbentuknya sebuah struktur universal tentang keadilan mesianik, suatu keadilan yang secara mutlak akan dimiliki oleh masa depan dan dengan demikian selalu "akan datang". ${ }^{9}$

Munculnya gerakan mesianik lazim didasarkan pada sebuah keyakinan akan hadirnya masa keemasan yang mengatakan bahwa semua ketidak adilan akan diakhiri dan dipulihkan dengan keharmonisan. Masa keemasan akan muncul setelah sebuah masa keprihatinan atau kondisi carut marut dan keterpurukan telah dilampaui. Dalam konteks keluar dari masa keprihatinan inilah muncul seorang pemimpin yang akan membawa para pengikutnya melewati krisis dan menikmati masa keemasan. ${ }^{10}$ Dalam gerakan membawa para pengikutnya ke masa keemasan itulah ideologi sebagai spirit gerakan menjadi penting adanya.

Menurut Kartodirjo, berdasarkan penelitiannya terhadap gerakan rakyat di Banten, terdapat lima ideologi yang selama ini mempengaruhi gerakan, yakni: millearisme, eskatologisme, messianisme, perang jihad dan revivalisme. ${ }^{11}$ Kendati terdapat beragam ideologi dalam gerakan perlawanan, namun semuanya dipacu oleh harapan akan hadirnya masa keemasan yang menggantikan masa keprihatinan dan keterpurukan. Dalam konteks ini, apa yang dilakukan oleh Hisbut Tahrir (HT) dan Majelis M ujahidin (MM) sebagai sebuah gerakan melawan Barat, juga didasarkan dengan keyakinan bahwa pada masa mendatang Islam akan memimpin kembali dunia sebagaimana yang telah dijanjikan oleh Allah dalam al-Qur'an, 24: 55.

Dalam konteks gerakan perlawanan ini, diperlukan adanya solidaritas komunal. $\mathrm{Hal}$ ini bisa dibangun dengan dasar sentimen-sentimen, perasaan-perasaan dan keterikatan-keterikatan di antara sesamanya. Gerakan perlawanan semacam ini akan terus muncul di sepanjang zaman, dan selalu disesuaikan dengan situasi-situasi terbaru. Dalam kerangka membawa massa kepada masa keadilan dan keharmonisan ini diperlukan sosok pemimpin. Pola kepemimpinan dalam konteks gerakan perlawanan tradisional adalah komunal dan kepatuhan. Kecenderungan komunal pada gerakan perlawanan dapat dilihat pada penggunaan simbol-simbol tertentu secara massal yang dimotivasi oleh sentimen dan perasaan keterikatan. Dalam konteks inilah kemudian posisi pemimpin yang tunggal menjadi sentral. Di samping itu, terjadi proses simbolis yang mengalami transformasi. Hal ini karena telah terjadi kontradiksi-kontradiksi budaya yang disebabkan oleh kekuatan-kekuatan hegemonik tertentu. ${ }^{12}$ Sebagai akibatnya, gerakan perlawaan bisa muncul karena adanya penyimpangan dan ancaman terhadap nilai, norma, pranata sosial-

\footnotetext{
${ }^{9}$ Thomas Santoso, Kekerasan Politik- Agama, Studi Konstruksi Sosial tentang Peruisakan Kinerja di Situbondo 1996 (Surabaya: Lutfansah Mediatama, 2003).

${ }^{10}$ Ipong Azhar, Radikalisasi Petani Masa O rde Baru: Kasus Sengketa Tanah J enggawah (Yogyakarta: Yayasan untuk Indonesia, 1999), 28.

${ }^{11}$ Sartono Kartodirjo, Ratu Adil (J akarta: Sinar Harapan, 1973), 5-6.

${ }^{12}$ Kuntowijoyo, Budaya dan Masyarakat (Yogyakarta: Tiara Wacana Yogya, 1999), 1-8.
} 
budaya dan agama. Dengan dasar ini pula, maka pertarungan ideologis merupakan tema terpenting dari gerakan perlawanan dimaksud.

MenurutKartodirjo, gerakan perlawanan juga akan muncul sebagai reaksi terhadap penetrasi dominasi kekuatan asing yang secara berangsur-angsur dapatmenghancurkan tatanan dan sendisendi kehidupan sosial dan keagamaan. ${ }^{13}$ Muatan ideologis yang menjadi spirit gerakan dan adanya seorang pemimpin sentral dalam konteks ini merupakan faktor penting bagi keberhasilan sebuah gerakan perlawanan.

\section{Beberapa Persoalan Kekerasan Agama}

Beberapa ekspresi kekerasan agama sesungguhnya bukanlah fenomena tunggal yang tidak terkait dengan apapun, atau hanya bisa dijelaskan lewat fenomena tersebut. la terkait dengan sejumlah persoalan, yang membantu memahami dan memperjelas persoalan kekerasan agama. Oleh karena itu, menilai satu ekspresi kekerasan sebagai "kengawuran", adalah penilaian yang terburu-buru. Bisa jadi kesimpulan dan penilaian tersebut benar adanya bagi kelompok lain, namun bagi pelaku bahwa apa yang dilakukan adalah kebaikan, atau bahkan tugas suci (in the name of $\mathrm{G}$ od). Dengan demikian, terdapat perbedaan cara pandang dari dua kelompok ini, yang berangkat dari standar yang juga berbeda. Kelompok penilai mengukurnya dari sisi kemanusiaan, namun kelompok pelaku menilainya sebagai tugas keagamaan. la sesungguhnya merupakan akumulasi dari berbagai fenomena yang kemudian melahirkan ekspresi tertentu misalnya bombing, teror, bunuh diri, dan kerusuhan. Karena itu, kekerasan agama bisa dijelaskan prosedurnya sebagai berikut:

1) Kekerasan bukan merupakan fenomena monolitik dan mandiri.

Ekspresi dan perilaku kekerasan bisa jadi terkait dengan faktor-faktor internal maupun eksternal manusia, namun juga bisa karena internal dan eksternal agama. Secara internal kemanusiaan, meminjam teori Fromm, ${ }^{14}$ bahwa sesungguhnya kekerasan merupakan bentuk penyaluran naluri destruktif yang ada dalam diri manusia. J ika kecenderungan manusia untuk tumbuh dihalangi, energi yang terhalang itu mengalami proses perubahan dan menjadi energi yang jahat dan merusak. Dengan demikian, kondisi individual dan sosial yang menghalangi energi yang memajukan kehidupan manusia, akan menghasilkan sifat perusakan, dan bisa menjadi sumber kekerasan.

Temuan psikologi terkini menyatakan bahwa naluri dominasi dan agresivitas adalah bawaan manusia sejak lahir. Bahkan J ohn Stuart Mill, sebagaimana disitir Fromm, ${ }^{15}$ menyatakan bahwa pelajaran pertama dari peradaban adalah pelajaran tentang kepatuhan. Manusia memiliki dua kecondongan, yakni hasrat untuk menggunakan kekuasaan atas orang lain; dan ketidakinginan menggunakan kekuasaan atas diri mereka sendiri". ${ }^{16}$ Kuatnya hasrat dan gairah untuk mematuhi dan diatur sebenarnya sama unggulnya dengan kehendak untuk berkuasa. Tampaknya dalam konteks politik hal tersebut lebih relevan.

\footnotetext{
${ }^{13}$ Kartodirjo, Ratu Adil, 25.

${ }^{14}$ Eric Fromm, Akar Kekerasan: Analisis Sosio-Psikologis atas Watak Manusia, ter. Imam Muttaqin (Yogyakarta:

Pustaka Pelajar, 2004), 227.

${ }^{15} \mathrm{Ibid}$.

${ }^{16}$ Hannah A rendt, Teori Kekerasan, ter. G hafna Raiza W. (Yogyakarta: LPIP, 2003 ), 35.
} 
Berlawanan dengan Fromm, Arendt ${ }^{17}$ menunjukkan penolakannya terhadap teori agresivitas sebagai bawaan manusia. H asil-hasil riset dalam ilmu sosial maupun alam cenderung untuk membuat perilaku kekerasan lebih sebagai reaksi alamiah. Dalam konteks ini, dapat diterima teori agresivitas sebagai sebuah dorongan naluriah yang memainkan peran fungsional yang sama dengan naluri-naluri nutritif dan seksual dalam proses kehidupan manusia. Namun, agresivitas selalu memerlukan provokasi dan faktor eksternal untuk membangkitkannya. ${ }^{18}$ Kekerasan yang mengatasnamakan agama, seringkali terjadi tidak hanya karena faktor internal agama, namun justru karena faktor eksternal. Dengan stimuli eksternal, potensi internal kekerasan agama akan dengan mudah tersulut.

2) Kekerasan muncul sebagai fenomena sosio-politik.

Perilaku kekerasan merupakan respons terhadap kegagalan atau tatanan sosio-politik yang ada. Kelompok pelaku kekerasan berupaya agar ideologi mereka menjadi satu-satunya alternatif yang dapat menggantikan tatanan yang ada. Harapannya adalah dapat mengentaskan manusia dari modernitas yang membuatnya tercerabut dari nilai-nilai agama. Amarah yang diekspresikan dengan kekerasan adalah reaksi terhadap kondisi-kondisi sosial tertentu yang diketahui dapat diubah menjadi lebih baik, namun tidak dilakukan perubahan untuk itu. ${ }^{19}$ Oleh karena itu, muncullah ideologi "dunia ketiga". Dalam konteks gerakan Islam "radikal", ideologi penyatuan dunia Islam dalam naungan khilafah islamiłah, sesungguhnya juga muncul sebagai respons terhadap ideologi-ideologi modern yang tidak mampu menyelesaikan permasalahan hidup manusia.

3) Kekerasan terjadi karena kondisi internal penganut agama.

Secara internal agama, fenomena kekerasan agama bisa jadi karena merupakan respons terhadap penyimpangan ajaran agama yang dilakukan oleh sekelompok orang. Karena itu, dalam perspektif kelompok tertentu, jalan kekerasan harus dilakukan dalam rangka melakukan pemurnian kembali agama yang telah terasuki penyakit takhayyul, bid'ah dan khurafat. Perjuangan gerakan pemurnian Wahhabi yang dimotori oleh Muhł̧mmad ibn 'A bd al-Wahhab di Saudi Arabia yang berkolaborasi dengan penguasa, gerakan purifikasi yang dilakukan Shah Waliy Allah di India melawan Islam sinkretik, gerakan purifikasi dalam Perang Padri di bawah pimpinan Imam Bonjol, adalah di antara bukti bahwa kondisi internal agama bisa menjadi pemicu yang begitu kuat melahirkan kekerasan.

4) Kekerasan memerlukan soliditas dan militansi kelompok.

Soliditas dan militansi gerakan kekerasan sangat tinggi. Dukungan keyakinan agama yang telah menjadi ideologi menjadikan kelompok ini sering melahirkan kekerasan terhadap kelompok lain yang diklaim salah karena berbeda ideologi. Praktek kekerasan mengikat manusia bersama sebagai sebuah keseluruhan, karena setiap individu membentuk sebuah jalinan kekerasan dalam rantai besar, sebuah bagan dari organisme besar yang telah menyeruak ke permukaan. ${ }^{20}$

\footnotetext{
$17 \mathrm{Ibid} ., 40$.

${ }^{18} \mathrm{Ibid}$., 59.

${ }^{19} \mathrm{lbid} ., 61$.

20 Ibid., 66.
} 
Kelompok pelaku kekerasan agama, misalnya, tidak akan pernah diperhatikan kecuali mereka terlibat dalam berbagai aksi dan provokasi. Oleh karena itu, dapat dipahami ketika para pelaku pengeboman maupun teror bom mengaku bertangggung jawab atas perbuatan tersebut. $\mathrm{H}$ al ini dimaksudkan agar mendapat perhatian publik bahwa eksistensi mereka harus "diakui" dan bisa menjadi oposan jika keinginan-keinginan ideologis mereka tidak dilaksanakan pihak penguasa. ${ }^{21}$

5) Kekerasan memiliki basis sistemik dalam sejarah survivalitas agama.

Kekerasan agama dapat berbasis pada motivasi spiritual dan makna religius. Ritual pengorbanan dan persembahan anak sebagaimana yang pernah dilakukan Ibrahin di Kan'an, merupakan salah satu contohnya. ${ }^{22}$ Motivasi religius dalam konteks ini terlihat lebih kuat dibanding dengan kecintaan terhadap anak. Manusia yang dalam kondisi demikian akan sangat taat terhadap sistem religinya. Karenanya dia tidak bisa disebut kejam, kendati orang lain di luar penganut sistem religi tersebut menganggapnya demikian. Dengan demikian, kepercayaan dan ketaatan terhadap doktrin agamanya semakin memperkokoh dan melegitimasi kekerasan yang dilakukannya.

Perjuangan kelompok radikalisme keagamaan, misalnya, dilakukan juga karena untuk memperoleh kebebasan dari cengkraman dan hegemoni kapitalisme, modernisme dan sekulerisme. Mereka meyakini bahwa Islam adalah satu-satunya ideologi alternatif yang membebaskan. Islam yang lengkap (shumub) akan mampu menjawab semua problem kehidupan. Sehingga dengan demikian, perjuangan melalui kekerasan tersebut ditujukan demi keberlangsungan dan menjaga citra Islam dan kaum Muslimin ('izz al-Islam wa almuslimia).

6) Kekerasan terkait dengan perasaan superioritas diri atas pihak lain.

Kekerasan bisa terjadi sebagai akibat terlukainya perasaan narsistik, yakni sikap mengagumi diri karena penilaian subyektif terhadap kesempurnaan, keunggulan, dan keluarbiasaannya, baik dalam konteks kebangsaan maupun keagamaan. ${ }^{23} \mathrm{Narsisisme} \mathrm{bisa}$ muncul dalam identitas individu maupun kelompok. Narsisisme kelompok ini bisa dipahami pada keyakinan gerakan kekerasan, yang dalam konteks Islam misalnya, yang mengagumi dan meyakini bahwa Islam adalah agama yang shumul>dan sempurna, sehingga agamaagama atau ideologi lain harus dikalahkan demi terlaksananya ke-shumul»an Islam. Sikap ini bisa mengakibatkan eksklusivitas yang karenannya pihak lain tidak perlu dihargai, bahkan jika perlu diperangi dan dihancurkan.

Narsisisme kelompok akan berfungsi memperkuat solidaritas dan keterpaduan kelompok. Sehingga mereka akan bereaksi keras terhadap segala bentuk pelecehan, baik yang nyata maupun yang samar, yang tertuju pada kelompoknya. ${ }^{24}$ Ketika simbol-simbol agamanya dilecehkan, maka dengan narsisismenya sebuah kelompok akan bereaksi keras dan radikal. Fenomena penggunaan simbol keagamaan oleh sebuah grup musik Dewa yang

\footnotetext{
${ }^{21}$ Fromm, Akar Kekerasan, 244.

22 Ibid., 281.

23 Ibid., 281

${ }^{24}$ Ibid., 284.
} 
kemudian direspons secara reaktif oleh Front Pembela Islam (FPI), membuktikan relevansi teori ini.

7) Kekerasan merupakan ekspresi ketaatan terhadap Tuhan.

Manusia memiliki fitrah (sifat dasar) yang menjadi esensinya. Untuk itu, ia membutuhkan kerangka orientasi fitrinya pada obyek ketaatan penuh sebagai titik pusat dari segala upaya dan landasan bagi semua nilai yang diyakininya. Dalam konteks ini, ketaatan bisa diarahkan pada dua pilihan, untuk kemajuan (taqwa)atau kehancuran (fujup), untuk mendapatkan cita atau sebaliknya. Kedua sindrom ini bisa berkembang karena manusia adalah makhluk yang "belum sempurna" diciptakan, bukan hanya karena otaknya yang belum berkembang, namun juga karena ketidakseimbangan yang menjadikan dirinya mengalami proses yang tak berujung dan tak berakhir. ${ }^{25}$

Kekerasan yang dilakukan oleh sebuah gerakan, karena mereka meyakini ada perintah untuk melakukannya dan berkewajiban menaatinya. Ketaatan tersebut bisa kepada Tuhan, teks agama, elit agama dan bahkan doktrin agama. ${ }^{26}$ O leh karena itu, dalam teologi-teologi agama, dipahami bahwa sesungguhnya relasi manusia dengan Tuhan merupakan relasi sederhana perintah dan kepatuhan. Pemahaman literal terhadap teks keagamaan juga bisa melahirkan ketaatan secara taken for granted untuk melakukan agresi dan kekerasan terhadap pihak lain.

8) Kekerasan terkait dengan persepsi tentang Tuhan dalam tradisi agama.

Tuhan dalam gambaran masing-masing agama atau pola keberagamaan mengalami "kekerasan" karena masing-masing memiliki konsepsi dan gambaran Tuhan yang berbedabeda. Gambaran Tuhan yang sadis dan perang akan berlawanan dengan gambaran Tuhan Pengasih dan Penyayang. $\mathrm{Hal}$ ini bisa mengakibatkan munculnya ekspresi keberagamaan sesuai dengan bagaimana gambaran mereka tentang Tuhannya. ${ }^{27}$

9) Kekerasan memerlukan legitimasi teologis.

Ekspresi kekerasan agama dalam konteks ini, misalnya, dapat dilihat pada gerakan zionisme, yang oleh kelompok Yahudi ortodoks diyakini bahwa penegakan dan perwujudan negara Israel sesungguhnya lebih dimotivasi oleh ekspresi ketaatan mereka terhadap keyakinan bahwa Israel adalah negara yang dijanjikan Tuhan kepada mereka. Dengan demikian, mereka akan dapat merealisasikan hukum Taurat yang selama ini tidak bisa diimplementasikan dalam diaspora, di bawah rezim-rezim dan ideologi yang sama sekali tidak memberikan kebebasan kepada kelompok Yahudi untuk "bernafas" dalam konteks ke-Yahudiannya. ${ }^{28}$ Dengan demikian, ia merupakan perang suci yang harus dikobarkan melawan semua pihak yang menentangnya. Dalam konteks ini adalah Arab Palestina yang diklaim sebagai perampas hak Yahudi. Perang suci ini menewaskan ribuan martir dari kedua belah pihak sebagai "ongkos" sosio-teologis yang terlalu mahal untuk sebuah keyakinan ideologis. Dengan demikian, identitas ke-Yahudian dibangun di atas kekerasan yang mengatasnamakan "perintah dan

\footnotetext{
${ }^{25}$ Ibid., 362.

${ }^{26} \mathrm{Ibid} ., 289$.

${ }^{27}$ Armstrong, Sejarah Tuhan, 46-47.

${ }^{28}$ Armstrong, Berperang Demi Tuhan, 233-234.
} 
ketaatan terhadap Tuhan".

Dalam konteks Kristen Baratyang berkeyakinan bahwa mereka adalah umat pilihan Tuhan, selama kurun perang Salib di abad ke 11-12 memikul tugas dan tanggung jawab yang tidak bisa dilakukan oleh Yahudi. Teologi keterpilihan ini, dalam semangat kaum Calvinis Amerika diyakini bahwa mereka sebangsa dengan Tuhan. Ekspresi kekerasan kelompok ini sering kali muncul dalam situasi kerawanan politik ketika mereka dihantui oleh ketakutan akan kehancuran diri. ${ }^{29}$

Ketika agama berfusi dengan aspek-aspek kehidupan lain, tidak jarang agama menjadi alat legitimasi kekerasan. Untuk memicu kekerasan, identitas agama individu menjelma menjadi homogenisasi komunal. Agama akan menjadi kekuatan dalam membangkitkan identitas emosional keagamaan, dibanding dengan identitas sosial lainnya. Dalam konteks inilah, analisis Kakar bahwa agama membawa konflik antar kelompok dengan intensitas emosi yang lebih besar dan motivasi pemaksaan yang lebih mendalam dibandingkan bahasa, daerah atau olokan terhadap identitas etnis lainnya, menemukan relevansinya. ${ }^{30}$

Dalam konteks ini pula, perlu dimajukan tesis B euken dan Kuschel ${ }^{31}$ yang berkesimpulan bahwa kekerasan atas nama agama bisa dilihat dari dua perspektif, yakni: pertama, pembacaan agama mengenai hubungan sosial, di mana agama merupakan legitimasi tersendiri bagi keabsahan perilaku kekerasan, karena memiliki fungsinya sebagai ideologi; kedua, agama sebagai faktor budaya identitas. Beberapa kasus kekerasan bernuansa agama, seperti konflik Suku Hutu dan Tutsi di Rwanda; kekerasan agama di Sri Lanka, di mana Kerajaan Singhalese dengan konsep nasionalisme Budhisnya, berperan aktif dalam pentas politik; kekerasan agama di Bosnia, yang merupakan representasi perang etnis dan budaya. Konflik dan kekerasan dimaksud, adalah bukti konkret betapa agama memiliki akar dan legitimasinya terhadap keabsahan perilaku kekerasan.

Beberapa warisan kekerasan atas nama agama, bisa disimak dalam beberapa kasus sejarah keislaman maupun kekristenan. Dalam sejarah Islam misalnya, kasus al-H allaj yang dihukum mati, Ibnu Rushd dihukum di depan masjid Kordoba, atau dalam konteks Indonesia adalah Shaykh Siti J enar yang dihukum pancung akibat menyalahi pola keberagamaan mainstream. Dalam sejarah Kristiani misalnya, juga bisa dilihat kasus Priscillian yang dihukum mati dan lainlain. Kendati berbau agama, namun sebenarnya tragedi kekerasan di atas tidak murni agama, tetapi juga terdapat faktor lain seperti politik, sosial dan bahkan interpretasi teologis.

Terdapat beberapa pijakan teologis tentang "perang suci atas nama agama" (holy war), yang interpretasinya sarat dan identik dengan kekerasan. Ini karena, dalam tradisi agama-agama, fenomena ini seakan memiliki legitimasi teologis tersendiri bagi survivalitas dan keberlangungan doktrin tersebut. Dengan demikian, terlalu sederhana untuk mengatakan bahwa kekerasan agama terjadi karena pembelokan makna teks-teks keagamaan, karena pada dasarnya tidak bisa dipungkiri bahwa ajaran agama memiliki unsur kekerasan. Hal ini juga bisa dilihat pada fakta

\footnotetext{
${ }^{29}$ Armstrong, Sejarah Tuhan, 90.

${ }^{30}$ Sudhir Kakar, The Colors of Violence Cultural Identities, Religion and Conflict (Chicago: U niversity of Chicago Press, 1996), 192.

${ }^{31}$ Beuken dan Kuschel, et al. Agama Sebagai Sumber Kekerasan?, ter. Iman Baehaqi (Yogyakarta: Pustaka Pelajar, 2003), xiv-xxv.
} 
penyebaran agama-agama, yang sarat dengan kekerasan. Belum lagi doktrin-doktrin keagamaan yang potensial menjadi pemicu kekerasan. Konsep jihad yang dimaknai sebagai perang fisik, polarisasi das al-Islam dan das al-hærb sehingga muncul identitas kawan dan lawan, konsep dakwah sebagai ideologi pengislaman dunia, maupun keyakinan akan uniformitas antara agama dan politik, adalah di antara isu-isu teologis yang seringkali memicu ekspresi kekerasan agama. Sumbangan kelompok Islam fundamentalis dalam menghadirkan fenomena kekerasan agama juga menarik untuk ditelisik, karena meyakini bahwa Islam bukan semata-mata agama, namun juga politik (al-islam diø wa dawlah).

Simbol-simbol keagamaan yang merupakan representasi masyarakat, seperti etnosentrisme agama Yahudi, agama Mormon di AS dan Sikh di India, dan lain lain demikian kental sifat komunalnya. ${ }^{32}$ Sehingga, melalui simbol-simbol inilah, komunalisme agama sering menjadi pemandangan dalam relasi agama-agama. Dengan semangat dan identitas komunalisme yang kuat, maka rentan memicu terjadinya kekerasan agama. Sekelompok orang yang hidup di wilayah tertentu atau dengan identitas tertentu, baik suku, etnis, ras maupun agama, memiliki ikatan emosional yang kuatsatu dengan yang lain. Sehingga ketika identitas mereka yang diekspresikan melalui simbol-simbol tertentu merasa terusik atau dilecehkan orang lain, dengan sangat cepat semangat komunalisme ini timbul.

Pendangkalan agama dalam transformasi masyarakat tradisional ke modern yang mengakibatkan hilangnya akar-akar psikologis dan kultural juga menjadi sebab lain dari merebaknya komunalisme agama-agama. Bercampur-baurnya agama dengan politik padahal keduanya adalah entitas yang berbeda, sehingga yang terjadi adalah politisasi agama, juga merupakan faktor yang tidak kalah menariknya bagi pembacaan kekerasan agama. ${ }^{33}$

Riyanto ${ }^{34}$ menyatakan bahwa kekerasan agama lebih disebabkan oleh sikap keagamaan yang fanatik (fanatisme), paham keagamaan yang fundamentalistis (fundamentalisme) dan integralisme. Dengan demikian, eksklusivisme sering dekat dengan konflik, pertikaian, dan kekerasan. Orang beragama yang menghadirkan kekerasan, disebabkan level keagamaannya yang jargonsentrisme, memperlihatkan keimanan yang logoistis, memiliki kekuatan bahasa yang provokatif, sempit dan rigid. Sehingga penghayatan yang kurang terhadap hakikat agama (being religious) menjadi sebab merebaknya komunalisme. $\mathrm{H}$ al ini karena agama merupakan entitas yang secara sosio-psikologis bertautan langsung dengan dimensi emosionalitas dan spiritualitas manusia.

\section{Penutup}

Kendati dalam agama terdapat ketentuan normatif yang bisa memunculkan kekerasan, namun sesungguhnya kekerasan terjadi karena faktor pemaknaan agama pada dataran historissosiologis. Agama yang disistematisir sebagai sebuah ideologi, akan berfungsi sebagai legitimasi yang bisa dipahami tidak saja oleh para pelaku kekerasan agama, namun juga oleh pihak lain. Ideologi juga bisa dijadikan sebagai daya perlawanan bagi sebuah tatanan yang mapan. Ketika

\footnotetext{
${ }^{32}$ Azyumardi Azra, Konteks Berteologi di Indonesia: Pengalaman Islam (J akarta: Paramadina, 1999), 18.

${ }^{33}$ A bdurrahman Wahid, "Dialog Agama dan Masalah Pendangkalan Agama", dalam Passing Over, 51-59.

${ }^{34}$ Armada Riyanto, "Membongkar Eksklusivisme Hidup Beragama", dalam Agama Kekerasan, 16-34.
} 
agama difungsikan sebagai ideologi, maka ia akan diformulasi dan ditaati oleh penganutnya untuk mencapai tujuan tertentu. Di samping itu, ia juga bisa digunakan oleh proponennya untuk mencapai tujuan politik. Secara lebih singkat, agama ideologis merupakan pendorong, penguat, dan simbol senjata politik.

\section{Daftar Rujukan}

Armstrong, Karen, the Battle for G od, Fundamentalism in J udaism, Cristianity and islam, (London: H arper Collins Publisher, 2003

Azhar, Ipong. Radikalisasi Petani Masa O rde Baru: Kasus Sengketa Tanah J enggawah. Yogyakarta: Yayasan untuk Indonesia, 1999.

Azra, Azyumardi. Konteks Berteologi di Indonesia: Pengalaman Islam. J akarta: Paramadina, 1999. Arendt, H annah. Teori Kekerasan, ter. G hafna Raiza W. Yogyakarta: LPIP, 2003.

B euken dan Kuschel, et al. Agama sebagai Sumber Kekerasan?, ter. Iman Baehaqi. Yogyakarta: Pustaka Pelajar, 2003, xiv-xxv.

Fromm, Eric. Akar Kekerasan: Analisis Sosio-Psikologis atas Watak Manusia, ter. Imam Muttaqin.Yogyakarta: Pustaka Pelajar, 2004.

Kakar, Sudhir. The Colors of Violence Cultural Identities : Religion and Conflict. Chicago: University of Chicago Press, 1996.

Kartodirjo, Sartono. Ratu Adil. J akarta: Sinar Harapan, 1973.

Kinloch, Graham C. Ideology and the Social Science. t.tp.: G reenwoon Press, 1981.

Kuntowijoyo. Budaya dan M asyarakat.Yogyakarta: Tiara Wacana Yogya, 1999.

Riyanto, Armada. "Genesis Terorisme", dalam Harian Umum Kompas, 22 O ktober 2002.

- - - . "Membongkar Eksklusivisme Hidup Beragama", dalam Agama Kekerasan, 16-34.

Samudera, Imam. Aku Melawan Teroris. Solo: Al-J azera, 2004.

Santoso, Thomas, Kekerasan Politik- Agama, Studi Konstruksi Sosial tentang Peruisakan Kinerja di Situbondo 1996, Surabaya: Lutfansah Mediatama, 2003

Tompson, J ohn B. Analisis Ideologi: Kritik Wacana Ideologi-ideologi Dunia. Yogyakarta: IRCiSoD, 2003.

Wahid, Abdurrahman. "Dialog Agama dan Masalah Pendangkalan Agama”, dalam Passing Over, 51-59. 